\title{
Assessment of Users' Perception towards the University Library Resources and Services of Sri Venkateswara University and Sri Krishna Devaraya University
}

\author{
T. Ramachandra Naidu ${ }^{1}$ and A. Kishore ${ }^{2}$ \\ ${ }^{1}$ Research Scholar, ${ }^{2}$ Assistant Professor \\ ${ }^{1 \& 2}$ Department of Library and Information Science, Dravidian University, Kuppam, Andhra Pradesh, India \\ E-Mail: rcnaidu5@gmail.com, saikishoresvu@gmail.com
}

\begin{abstract}
This paper aims to explore the assessment of users' perception towards the university libraries resources and services. A well structured questionnaire was designed to elicit the opinion of users. Responses were gathered from 120 PG students and Research scholars in Sri Venkateswara University and Sri Krishna Devaraya University of Andhra Pradesh state as a pilot study. On the basis of the findings, some suggestions have been put forth for maximizing the use of sources and services of university libraries.

Keywords: University libraries sources and services, Sri Venkateswara University, Sri Krishna Devaraya University
\end{abstract}

\section{INTRODUCTION}

The main aim of the University library is to support the University in the area of learning, teaching and research. The library is regarded as the heart of any academic organization. University libraries all over world have their own place of importance in the scheme of higher learning. Libraries are not only repositories of knowledge but also dispensers of such knowledge. There is no doubt that where libraries of universities and institutions of higher learning are ignored or not given due recognition, the country as a whole suffers because the standards of study, teaching and research very heavily depend upon the qualities and quantitative service rendered by the university libraries.

Library sources and services are important aspects in any kind of library. Libraries are providing information from their sources of information. Traditionally speaking, library sources include books, periodicals, and newspapers. However, the number and forms of sources of are continuously increasing. Even unpublished sources are becoming increasingly important in all types of libraries. University libraries are services oriented centers that should provide priority to the needs of the students.

\section{A. About S. V. University (SVU) and S. K. University (SKU) Libraries}

S.V. University library' was established in 1954. It has its own building. It subscribes to 600 current periodicals. It has stock of 3,85,000 includes books and back volumes of periodicals. It provides photocopying service, documentation and abstracting service and Internet services. Its membership is 6000 .
Sri Krishnadevaraya University Library was established in the year 1981. The total collection of books and back volumes of periodicals is $1,27,000$. It subscribes to 165 current periodicals. It offers reference service, reprographic service and current awareness service and Internet. The total membership is 3000 . Its annual budget for current periodicals is Rs.5.5 lakhs.

\section{REVIEW OF LITERATURE}

Many studies have concentrated to know the use of information resources and services in the libraries.

Kumar, V. D. \& Kumar, S. (2018) focused the study on the usage and users of employment bureau library of Kuvempu University. Study identified that the existence of the library is very significant for the graduates and research scholars who are studying in different departments of the university. Study clearly indicated that $96.7 \%$ of respondents have completed their bachelor degree and pursuing their masters' degree. Even though the library users are from rural background they had the awareness regarding the library membership (84.7\%). Their visit frequency to the library is daily followed by twice in a week. More than $60 \%$ of responses indicated that they spend one to two hours in the library. This shows their urge to use the library for employment and career oriented information. The respondents are highly aware of reference service followed by reading room facility offered by Employment Bureau library of Kuvempu University.

Kurian, Binoy and Nagarajan, M (2018) attempts to examine the awareness and use of open access resources by the research scholars of Annamalai University. A structured questionnaire was employed to collect the data. A total of 2066 questionnaire were distributed. Of which 1941 questionnaire duly filled in were received back. The major findings of the study were $94.59 \%$ Research scholars are well aware of different categories of open access resources, The most prominent sources are e-journals, electronic theses and dissertations and e-books, 40.80 percent of the research scholars spent about 11-15 hours a month, 94.59 percent of the respondents made use of open access resources for research purpose, 50.86 percent of the respondents were 
moderate level satisfied, 74.43 percent of the research scholars opined that lack of speed was a major constraint faced by the respondents.

Dumebi, Otulugbu (2017) investigated the awareness and use of online information sources among university of Ibadan undergraduate students. Findings show that $97.9 \%$ of the students were generally aware of online information sources but very few of the students were aware of the individual online sources that are made available in the university. This study suggests that university libraries should effectively create awareness about the various online resources that available for students' usage.

Javed Khan (2016) examines the use of collections and services at IIT Delhi Library. A well structured 120 questionnaires were distributed among IIT Delhi users during the academic session 2015 - 16, to find out the user of information resources is being provided by IIT library. The sample of 100 users i.e. UG, PG and faculty members. Based on the findings the researcher suggested that library should make an arrangement to endow with nascent information to the users. Access to every document in a library should be possible through a proper system 3 . Library should arrange more multiple copies of documents in all fields. Books of latest edition should be acquired. Library should also acquire more reference sources to satisfy the needs of the users.

Ramadevi (2016) carried out a survey study on information resources and services in the public libraries of Warangal district Telangana state, India. The study revolved that the majority of the users were men between the age group of 11-30 years they were students, unemployed, Govt. employee and employee of private sector. The available resources used by the user and their visiting frequently, books and magazines, friends/teachers and radio/television where the information channels most frequently used to satisfy their information needs. Reading room and book lending services where the most frequently used services. This paper also discusses a few suggestions to make the service more beneficial for the community at large.

Fatima, Farheen and Tadasad, P G (2013) undertaken a study to find out the user's attitude comprising of all categories of users of Gulbarga University Library, Gulbarga towards library resources. Based on the survey of 219 users through a questionnaire as a tool for data collection, the paper analysis's the results on awareness, requirement, usage, comprehensiveness, up-to-datedness, adequacy including satisfaction level among the users regarding collection.

Zabed Ahmed (2013) in his survey of students in two specialized universities in a developing country to assess their use and satisfaction with university subscribed online resources, found that the students were not satisfied with the level of their university's subscribed online resources. The students identified limited access to computers and slow download speed as major problems.

Thanuskodi, S. (2012) studied the use of e-resources by the post graduate students and research scholars of Faculty of Arts in the Annamalai University. A total of 200 questionnaires were distributed to the selected sample of Faculty of Arts; 180 valid samples were collected. The study found that the majority of users are aware about the availability of e-resources. The result reveals that $47.78 \%$ of respondents want to access only electronic version whereas only $32.78 \%$ users want to read the printed journals but $19.44 \%$ respondents want to use both electronic and printed version.

Mahajan (2009) examined the information seeking habit of students in the sciences, social sciences and Humanities at the Punjub University of India. He discovered that they were not fully satisfied with the online information services due to inefficiency on the part of the library. The library has not fully understood the increasing dynamics in the tools and methods of information search.

\section{OBJECTIVES OF THE STUDY}

1. To find the frequency of the using the library by the users.

2. To examine the time spent and purpose of visiting the library.

3. To identify the aware of the print resources and electronic resources.

4. To assess the impact of library resources and services on their learning.

5. To examine the problems encountered by the users while accessing information resources and services.

6. To ascertain the level of satisfaction of users by the usage of various information resources and services.

\section{METHODOLOGY}

The present study has been conducted using survey method of research. Questionnaire has been used as a data collection tool. The population of the study comprises of the PG students and research scholars. Since the population is large, sampling technique is used to limit the size and to draw an appropriate sample which is a representative of the entire population. Questionnaires are distributed among the units of the sample for collecting data. The study has been conducted during February -June, 2018. So the study reports only the preliminary investigation carried out as a Pilot Study to ascertain the possibility of study at larger scale. Altogether 120 questionnaires have been distributed among the two categories, viz., the research scholars and the PG students of Sri Venkateswara University and Sri Krishna Devaraya University of Andhra Pradesh state and requested them to fill the questionnaire as per their convenience and return the questionnaire to the investigator as early as possible. The filled up questionnaire has been collected from the respondents for the data analysis and interpretation. 


\section{DATA ANALYSIS}

TABLE I Age Wise Distribution Of RESPONDENTS

\begin{tabular}{|l|c|c|c|c|c|}
\hline \multirow{3}{*}{ Age } & \multicolumn{2}{|c|}{ SVU } & \multicolumn{2}{c|}{ SKU } & \multirow{2}{*}{ Total } \\
\cline { 2 - 5 } & $\begin{array}{c}\text { P.G } \\
\text { N=30 }\end{array}$ & $\begin{array}{c}\text { R.S } \\
\mathbf{N = 3 0}\end{array}$ & $\begin{array}{c}\text { P.G } \\
\mathbf{N = 3 0}\end{array}$ & $\begin{array}{c}\text { R.S } \\
\mathbf{N = 3 0}\end{array}$ & \\
\hline $\begin{array}{l}\text { Below 22 } \\
\text { years }\end{array}$ & 1 & 1 & 1 & 1 & 4 \\
& $(3.33)$ & $(3.33)$ & $(3.33)$ & $(3.33)$ & $(3.33)$ \\
\hline 23-24 years & 19 & 5 & 27 & 3 & 54 \\
& $(63.33)$ & $(16.67)$ & $(90.00)$ & $(10.00)$ & $(45.00)$ \\
\hline 25-28 years & 6 & 20 & 1 & 23 & 50 \\
& $(20.00)$ & $(66.67)$ & $(3.33)$ & $(76.67)$ & $(41.67)$ \\
\hline 29 and & 4 & 4 & 1 & 3 & 12 \\
above years & $(13.33)$ & $(13.33)$ & $(3.33)$ & $(10.00)$ & $(10.00)$ \\
\hline Total & 30 & 30 & 30 & 30 & 120 \\
& $(100)$ & $(100)$ & $(100)$ & $(100)$ & $(100.00)$ \\
\hline
\end{tabular}

Table I shows that almost half of the respondents $(45 \%)$ are aged between 23-24 years, 41.67 per cent of them are in the age group of 25-28 years, 10 per cent of them are 29 and above years and the remaining 3.33 per cent are below 22 years. It is evident from the table that majority of the respondents are in the age group of 23-24 years.

TABLE II GENDER Wise DisTRIBUTION OF RESPONDENTS

\begin{tabular}{|l|c|c|c|c|c|}
\hline \multirow{2}{*}{ Gender } & \multicolumn{2}{|c|}{ SVU } & \multicolumn{2}{c|}{ SKU } & \multirow{2}{*}{ Total } \\
\cline { 2 - 5 } & PG & RS & PG & RS & \\
\hline \multirow{2}{*}{ Male } & 23 & 19 & 18 & 24 & 84 \\
& $(76.67)$ & $(63.33)$ & $(60.00)$ & $(80.00)$ & $(70.00)$ \\
\hline \multirow{2}{*}{ Female } & 7 & 11 & 12 & 6 & 36 \\
& $(23.33)$ & $(36.67)$ & $(40.00)$ & $(20.00)$ & $(30.00)$ \\
\hline \multirow{2}{*}{ Total } & 30 & 30 & 30 & 30 & 120 \\
& $(100)$ & $(100)$ & $(100)$ & $(100)$ & $(100)$ \\
\hline
\end{tabular}

Table II indicates the gender wise distribution of respondents visit to the university libraries. It is clear from the table that out of 120 respondents, nearly three-fourths of the respondents $(70 \%)$ are male and the remaining onefourth $(30 \%)$ of the respondents are female.

TABLE III Status Wise Distribution Of ResPondents

\begin{tabular}{|l|c|c|c|}
\hline \multicolumn{1}{|c|}{ Status } & $\begin{array}{c}\text { SVU } \\
\mathbf{N = 6 0}\end{array}$ & $\begin{array}{c}\text { SKU } \\
\mathbf{N = 6 0}\end{array}$ & $\begin{array}{c}\text { Total } \\
\mathbf{N = 1 2 0}\end{array}$ \\
\hline Post Graduate Students & $\begin{array}{c}30 \\
(50.00)\end{array}$ & $\begin{array}{c}30 \\
(50.00)\end{array}$ & $\begin{array}{c}60 \\
(50.00)\end{array}$ \\
\hline Research Scholars & $\begin{array}{c}30 \\
(50.00)\end{array}$ & $\begin{array}{c}30 \\
(50.00)\end{array}$ & $\begin{array}{c}60 \\
(50.00)\end{array}$ \\
\hline Total & $\begin{array}{c}60 \\
(100)\end{array}$ & $\begin{array}{c}60 \\
(100)\end{array}$ & $\begin{array}{c}120 \\
(100)\end{array}$ \\
\hline
\end{tabular}

It is evident from the table III that 50 percent of the respondents are Post-Graduate students and the same 50 per cent of them are Research Scholars.

Data presented in table IV indicates the respondent's frequency of visit to the university libraries. It could be noted that out of the total 120 respondents, $64.17 \%$ of the respondents are visit daily, 13.33 percent of the respondents are visit twice a week and ones a week respectively, 5.83 percent of the respondents are visit twice a month and remaining 3.33 percent of the respondents are visit occasionally.
TABLE IV HOW OFTEN USING THE LIBRARY

\begin{tabular}{|c|c|c|c|c|c|}
\hline \multirow[b]{2}{*}{$\begin{array}{l}\text { Often to use } \\
\text { the library }\end{array}$} & \multicolumn{2}{|c|}{ SVU } & \multicolumn{2}{|c|}{ SKU } & \multirow[b]{2}{*}{ Total } \\
\hline & $\begin{array}{c}\text { PG } \\
\mathbf{N}=\mathbf{3 0}\end{array}$ & $\begin{array}{c}\text { RS } \\
\mathbf{N}=\mathbf{3 0}\end{array}$ & $\begin{array}{c}\text { PG } \\
\mathrm{N}=\mathbf{3 0}\end{array}$ & $\begin{array}{c}\text { RS } \\
\mathbf{N}=\mathbf{3 0}\end{array}$ & \\
\hline Daily & $\begin{array}{c}25 \\
(83.33)\end{array}$ & $\begin{array}{c}12 \\
(40.00)\end{array}$ & $\begin{array}{c}23 \\
76.67)\end{array}$ & $\begin{array}{c}15 \\
(50.00)\end{array}$ & $\begin{array}{c}77 \\
(64.17)\end{array}$ \\
\hline $\begin{array}{l}\text { Twice a } \\
\text { week }\end{array}$ & $\begin{array}{c}2 \\
(6.67)\end{array}$ & $\begin{array}{c}8 \\
(26.67)\end{array}$ & $\begin{array}{c}3 \\
(10.00)\end{array}$ & $\begin{array}{c}3 \\
(10.00)\end{array}$ & $\begin{array}{c}16 \\
(13.33) \\
\end{array}$ \\
\hline Once a week & $\begin{array}{c}1 \\
(3.33)\end{array}$ & $\begin{array}{c}6 \\
(20.00)\end{array}$ & $\begin{array}{c}2 \\
(6.67)\end{array}$ & $\begin{array}{c}7 \\
(23.33)\end{array}$ & $\begin{array}{c}16 \\
(13.33)\end{array}$ \\
\hline $\begin{array}{l}\text { Twice a } \\
\text { month }\end{array}$ & $\begin{array}{c}1 \\
(3.33)\end{array}$ & $\begin{array}{c}2 \\
(6.67)\end{array}$ & $\begin{array}{c}1 \\
(3.33)\end{array}$ & $\begin{array}{c}3 \\
(10.00)\end{array}$ & $\begin{array}{c}7 \\
(5.83)\end{array}$ \\
\hline Occasionally & $\begin{array}{c}1 \\
(3.33) \\
\end{array}$ & $\begin{array}{c}2 \\
(6.67) \\
\end{array}$ & $\begin{array}{c}1 \\
(3.33) \\
\end{array}$ & $\begin{array}{c}2 \\
(6.67)\end{array}$ & $\begin{array}{c}4 \\
(3.33) \\
\end{array}$ \\
\hline Total & $\begin{array}{c}30 \\
(100)\end{array}$ & $\begin{array}{c}30 \\
(100)\end{array}$ & $\begin{array}{c}30 \\
(100)\end{array}$ & $\begin{array}{c}30 \\
(100)\end{array}$ & $\begin{array}{l}120 \\
(100)\end{array}$ \\
\hline
\end{tabular}

Data presented in table IV indicates the respondent's frequency of visit to the university libraries. It could be noted that out of the total 120 respondents, $64.17 \%$ of the respondents are visit daily, 13.33 percent of the respondents are visit twice a week and ones a week respectively, 5.83 percent of the respondents are visit twice a month and remaining 3.33 percent of the respondents are visit occasionally.

TABLE V Time SPENT In The LibraRy

\begin{tabular}{|l|c|c|c|c|c|}
\hline \multirow{2}{*}{ Time spent } & \multicolumn{2}{|c|}{ SVU } & \multicolumn{2}{c|}{ SKU } & \multirow{2}{*}{ Total } \\
\cline { 2 - 5 } & $\begin{array}{c}\text { PG } \\
\mathbf{N = 3 0}\end{array}$ & $\begin{array}{c}\text { RS } \\
\mathbf{N = 3 0}\end{array}$ & $\begin{array}{c}\text { PG } \\
\mathbf{N = 3 0}\end{array}$ & $\begin{array}{c}\text { RS } \\
\mathbf{N = 3 0}\end{array}$ & \\
\hline $\begin{array}{l}\text { Below 30 } \\
\text { minutes }\end{array}$ & $\begin{array}{c}3 \\
(10.00)\end{array}$ & $\begin{array}{c}6 \\
(20.00)\end{array}$ & $\begin{array}{c}2 \\
(6.67)\end{array}$ & $\begin{array}{c}1 \\
(3.33)\end{array}$ & $\begin{array}{c}12 \\
(10.00)\end{array}$ \\
\hline $\begin{array}{l}\text { From 30 } \\
\text { minutes to 1 } \\
\text { hour }\end{array}$ & $\begin{array}{c}7 \\
(23.33)\end{array}$ & $\begin{array}{c}12 \\
(40.00)\end{array}$ & $\begin{array}{c}9 \\
(30.00)\end{array}$ & $\begin{array}{c}17 \\
(56.67)\end{array}$ & $\begin{array}{c}45 \\
(37.50)\end{array}$ \\
\hline $1-2$ hours & $\begin{array}{c}13 \\
(43.33)\end{array}$ & $\begin{array}{c}9 \\
(30.00)\end{array}$ & $\begin{array}{c}16 \\
(53.33)\end{array}$ & $\begin{array}{c}9 \\
(30.00)\end{array}$ & $\begin{array}{c}47 \\
(39.17)\end{array}$ \\
\hline 2 -3 hours & $\begin{array}{c}4 \\
(13.33)\end{array}$ & $\begin{array}{c}2 \\
(6.67)\end{array}$ & $\begin{array}{c}2 \\
(6.67)\end{array}$ & $\begin{array}{c}2 \\
(6.67)\end{array}$ & $\begin{array}{c}10 \\
(8.33)\end{array}$ \\
\hline $\begin{array}{l}\text { More than 3 } \\
\text { hours }\end{array}$ & $\begin{array}{c}3 \\
(10.00)\end{array}$ & $\begin{array}{c}1 \\
(3.33)\end{array}$ & $\begin{array}{c}1 \\
(3.33)\end{array}$ & $\begin{array}{c}1 \\
(3.33)\end{array}$ & $\begin{array}{c}6 \\
(5.00)\end{array}$ \\
\hline Total & $\begin{array}{c}30 \\
(100)\end{array}$ & $\begin{array}{c}30 \\
(100)\end{array}$ & $\begin{array}{c}30 \\
(100)\end{array}$ & $\begin{array}{c}30 \\
(100)\end{array}$ & $\begin{array}{c}120 \\
(100)\end{array}$ \\
\hline
\end{tabular}

It is evident from table $\mathrm{V}$ that 39.17 per cent of total users spent 1-2 hours time per day to use resources and services followed by 37.50 per cent from 30 minutes to 1 hour, 10.00 per cent below 30 minutes, 8.33 percent $2-3$ hours and remaining 5.00 per cent are using more than 3 hours.

The respondents were asked about the purpose of visiting the library. The replies given by them are presented in Table VI All SVU PG users (100\%) visit the library for the purpose of news paper reading and taking printouts followed by for book reading and using Internet (E-mails, WWW etc.) (96.67\%), for photocopying (93.33\%), for using competitive examination books where as all Research Scholars visiting library for using reference books, newspaper reading, using Internet (E-mails, WWW etc.) $(100 \%)$, followed by book reading $(90 \%)$, photocopying and using dissertations/theses reports $(86.67 \%)$. 
Similarly all SKU PG users (100\%) purpose is for newspaper reading, using Internet (E-mails, WWW etc.) and photocopying followed by for using reference books (96.67\%), book reading and using competitive examination books $(93.33 \%)$ where as all Research Scholars (100\%) visit library for the purpose of using reference books, newspaper reading, using Internet (E-mails, WWW etc.) followed by for using dissertations/theses reports $(93.33 \%)$, taking print outs $(90 \%)$.

TABLE VI PuRPose OF Visiting OF THE LiBRARY

\begin{tabular}{|l|c|c|c|c|}
\hline \multirow{2}{*}{$\begin{array}{c}\text { Purpose of } \\
\text { visiting }\end{array}$} & \multicolumn{2}{c|}{ SVU } & \multicolumn{2}{c|}{ SKU } \\
\cline { 2 - 5 } & $\begin{array}{c}\text { PG } \\
\text { N=30 }\end{array}$ & $\begin{array}{c}\text { RS } \\
\text { N=30 }\end{array}$ & $\begin{array}{c}\text { PG } \\
\mathbf{N = 3 0}\end{array}$ & $\begin{array}{c}\text { RS } \\
\text { N=30 }\end{array}$ \\
\hline Book reading & $\begin{array}{c}29 \\
(96.67)\end{array}$ & $\begin{array}{c}27 \\
(90.00)\end{array}$ & $\begin{array}{c}28 \\
(93.33)\end{array}$ & $\begin{array}{c}26 \\
(86.67)\end{array}$ \\
\hline $\begin{array}{l}\text { Borrowing and } \\
\text { returning of } \\
\text { reading materials }\end{array}$ & $\begin{array}{c}15 \\
(50.00)\end{array}$ & $\begin{array}{c}12 \\
(40.00)\end{array}$ & $\begin{array}{c}19 \\
(63.33)\end{array}$ & $\begin{array}{c}14 \\
(46.67)\end{array}$ \\
\hline $\begin{array}{l}\text { Using reference } \\
\text { books }\end{array}$ & $\begin{array}{c}23 \\
(76.67)\end{array}$ & $\begin{array}{c}30 \\
(100.00)\end{array}$ & $\begin{array}{c}29 \\
(96.67)\end{array}$ & $\begin{array}{c}30 \\
(100.00)\end{array}$ \\
\hline $\begin{array}{l}\text { Consulting current } \\
\text { print periodicals }\end{array}$ & $\begin{array}{c}8 \\
(26.67)\end{array}$ & $\begin{array}{c}25 \\
(83.33)\end{array}$ & $\begin{array}{c}11 \\
(36.67)\end{array}$ & $\begin{array}{c}23 \\
(76.67)\end{array}$ \\
\hline Newspaper reading & $\begin{array}{c}30 \\
(100.00)\end{array}$ & $\begin{array}{c}30 \\
(100.00)\end{array}$ & $\begin{array}{c}30 \\
(100.00)\end{array}$ & $\begin{array}{c}30 \\
(100.00)\end{array}$ \\
\hline $\begin{array}{l}\text { Using competitive } \\
\text { examination books }\end{array}$ & $\begin{array}{c}25 \\
(83.33)\end{array}$ & $\begin{array}{c}17 \\
(56.67)\end{array}$ & $\begin{array}{c}28 \\
(93.33)\end{array}$ & $\begin{array}{c}12 \\
(40.00)\end{array}$ \\
\hline $\begin{array}{l}\text { Searching online } \\
\text { journals/databases }\end{array}$ & $\begin{array}{c}5 \\
(16.67)\end{array}$ & $\begin{array}{c}24 \\
(80.00)\end{array}$ & $\begin{array}{c}9 \\
(30.00)\end{array}$ & $\begin{array}{c}16 \\
(53.33)\end{array}$ \\
\hline $\begin{array}{l}\text { Using audio-visual } \\
\text { materials }\end{array}$ & 7 & 11 & 9 & 16 \\
$(23.33)$ & $(36.67)$ & $(30.00)$ & $(53.33)$ \\
\hline $\begin{array}{l}\text { Using Internet (E- } \\
\text { mails, WWW etc.) }\end{array}$ & $\begin{array}{c}29 \\
(96.67)\end{array}$ & $\begin{array}{c}30 \\
(100.00)\end{array}$ & $\begin{array}{c}30 \\
(100.00)\end{array}$ & $\begin{array}{c}30 \\
(100.00)\end{array}$ \\
\hline $\begin{array}{l}\text { Getting } \\
\text { information about } \\
\text { career } \\
\text { opportunities }\end{array}$ & $\begin{array}{c}22 \\
(73.33)\end{array}$ & $\begin{array}{c}19 \\
(63.33)\end{array}$ & $\begin{array}{c}20 \\
(66.67)\end{array}$ & $\begin{array}{c}16 \\
(53.33)\end{array}$ \\
\hline Taking print outs & $\begin{array}{c}30 \\
(100.00)\end{array}$ & $\begin{array}{c}30 \\
(100.00)\end{array}$ & $\begin{array}{c}20 \\
(66.67)\end{array}$ & $\begin{array}{c}27 \\
(90.00)\end{array}$ \\
\hline Photocopying & 28 & 26 & 30 & 24 \\
$(93.33)$ & $(86.67)$ & $(100.00)$ & $(80.00)$ \\
\hline $\begin{array}{l}\text { Using } \\
\text { dissertations/theses } \\
\text { reports }\end{array}$ & $\begin{array}{c}6 \\
(20.00)\end{array}$ & $\begin{array}{c}26 \\
(86.67)\end{array}$ & $\begin{array}{c}8 \\
(26.67)\end{array}$ & $\begin{array}{c}28 \\
(93.33)\end{array}$ \\
\hline
\end{tabular}

TABle VII Getting The ReQuired ReAding Materials/ Resources

\begin{tabular}{|l|c|c|c|c|}
\hline \multirow{2}{*}{$\begin{array}{c}\text { Getting the required } \\
\text { reading materials }\end{array}$} & \multicolumn{2}{c|}{$\begin{array}{c}\text { SVU } \\
\text { N=60 }\end{array}$} & \multicolumn{2}{c|}{$\begin{array}{c}\text { SKU } \\
\text { N=60 }\end{array}$} \\
\cline { 2 - 5 } & No. & $\mathbf{\%}$ & No. & \% \\
\hline Family members & 24 & 40.00 & 19 & 31.67 \\
\hline Personal book collection & 29 & 48.33 & 13 & 21.67 \\
\hline Friends & 57 & 95.00 & 50 & 83.33 \\
\hline Book shops & 45 & 75.00 & 49 & 81.67 \\
\hline Internet browsing/websites & 58 & 96.67 & 60 & 100.00 \\
\hline Faculty members & 60 & 100.00 & 56 & 93.33 \\
\hline University library & 60 & 100.00 & 60 & 100.00 \\
\hline
\end{tabular}

A question has been put to the respondents to know the sources they consult to get required reading material. The replies given by them are presented in Table VII. The Table represents that all the SVU library users (100\%) replied that they depend on faculty members and university library for reading materials followed by Internet browsing/websites (96.67\%), friends $(95 \%)$, book shops $(75 \%)$, personal book collection (48.33\%) and family members $(40 \%)$ respectively. All the SKU library users (100\%) replied that they depend on Internet browsing/websites and university library for reading materials followed by faculty members $(93.33 \%)$, friends $(83.33 \%)$, book shops $(81.67 \%)$, family members $(31.67 \%)$ and personal book collection (21.67\%) respectively.

TABLE VIII AwARE Of THE PRINT RESOURCES

\begin{tabular}{|l|c|c|c|c|}
\hline \multirow{2}{*}{\multicolumn{1}{c|}{ Print Resources }} & \multicolumn{2}{c|}{$\begin{array}{c}\text { SVU } \\
\text { N=60 }\end{array}$} & \multicolumn{2}{c|}{$\begin{array}{c}\text { SKU } \\
\text { N=60 }\end{array}$} \\
\cline { 2 - 5 } & No. & \% & No. & $\%$ \\
\hline Textbooks & 60 & 100.00 & 60 & 100.00 \\
\hline Reference books/sources & 60 & 100.00 & 30 & 50.00 \\
\hline Printed journals / magazines & 45 & 75.00 & 49 & 81.66 \\
\hline Newspapers & 60 & 100.00 & 60 & 100.00 \\
\hline Back volume of periodicals & 20 & 33.33 & 25 & 41.66 \\
\hline University publications & 12 & 20.00 & 24 & 40.00 \\
\hline Theses/dissertations & 48 & 80.00 & 30 & 50.00 \\
\hline
\end{tabular}

It is evident from the table VIII that all the SVU library users replied that they are aware of textbooks $(100.00 \%)$, reference books $(100.00 \%)$ and newspapers $(100.00 \%)$. It is also evident from the table that majority of the users are aware of Thesis \& dissertations (80\%), printed journals / magazines $(75 \%)$, back volume of periodicals $(33.33$ and the institutional publications (20\%). Among SKU library users, $100 \%$ aware of textbooks and newspapers followed by printed journals / magazines (81.66\%), reference books/sources and theses and dissertations (50\%), back volumes of periodicals $(41.66 \%)$ and university publications $(40 \%)$.

TABLE IX AWARE OF THE ELECTRONIC-RESOURCES

\begin{tabular}{|l|c|c|c|c|}
\hline \multirow{2}{*}{ Electronic Resources } & \multicolumn{2}{|c|}{$\begin{array}{c}\text { SVU } \\
\text { N=60 }\end{array}$} & \multicolumn{2}{c|}{$\begin{array}{c}\text { SKU } \\
\text { N=60 }\end{array}$} \\
\cline { 2 - 5 } & No. & $\mathbf{\%}$ & No. & \% \\
\hline Internet / E-mail & 30 & 50.00 & 30 & 50.00 \\
\hline $\begin{array}{l}\text { Electronic } \\
\text { journals/magazines }\end{array}$ & 21 & 35.00 & 18 & 30.00 \\
\hline Electronic books & 27 & 45.00 & 26 & 43.33 \\
\hline CD/DVD's databases & 20 & 33.3 & 17 & 28.33 \\
\hline E-Theses & 22 & 36.67 & 26 & 43.33 \\
\hline $\begin{array}{l}\text { Online Public Access } \\
\text { Catalogue (OPAC) }\end{array}$ & 28 & 46.67 & 26 & 43.33 \\
\hline News groups & 19 & 31.67 & 23 & 38.33 \\
\hline Audio visual sources & 16 & 26.67 & 19 & 31.67 \\
\hline Open access resources & 21 & 35.00 & 18 & 30.00 \\
\hline
\end{tabular}


It is evident from the table IX that half of the SVU library users replied that they are aware of Internet / E-mail (50\%) followed by Online Public Access Catalogue (OPAC) (46.67\%), electronic books (45\%), e-Theses (36.67\%), electronic journals/magazines and Open access resources (35\%), news groups $(31.67 \%)$, audio visual sources $(26.67 \%)$ respectively. It is also observed from the above table that half of the SKU library users replied that they are aware of Internet / E-mail (50\%) followed by electronic books, e-Theses, Online Public Access Catalogue (OPAC) $(43.33 \%)$, news groups (38.33), audio visual sources (31.67\%), electronic journals/magazines and open access resources 930\%) and CD/DVD's databases (28.33\%) respectively.

TABLE X UNIVERSITY STUDENTS ARE THE MAJOR BENEFICIARY GROUP OF UNIVERSITY LIBRARY

\begin{tabular}{|l|c|c|c|c|c|}
\hline Beneficiary & \multicolumn{2}{|c|}{ SVU } & \multicolumn{2}{c|}{ SKU } & \\
\cline { 2 - 5 } $\begin{array}{c}\text { group of } \\
\text { university } \\
\text { library }\end{array}$ & $\begin{array}{c}\text { P.G } \\
\text { N=30 }\end{array}$ & $\begin{array}{c}\text { R.S } \\
\text { N=30 }\end{array}$ & $\begin{array}{c}\text { P.G } \\
\text { N=30 }\end{array}$ & $\begin{array}{c}\text { R.S } \\
\text { N=30 }\end{array}$ & \\
\hline Agree & 16 & 18 & 13 & 11 & 58 \\
& $(53.33)$ & $(60.00)$ & $(43.33)$ & $(36.67)$ & $(48.33)$ \\
\hline Strongly & 13 & 10 & 16 & 18 & 57 \\
Agree & $(43.34)$ & $(33.33)$ & $(53.33)$ & $(60.00)$ & $(47.50)$ \\
\hline Neutral & 1 & 2 & 1 & 1 & 5 \\
& $(3.33)$ & $(6.67)$ & $(3.33)$ & $(3.33)$ & $(4.17)$ \\
\hline Total & 30 & 30 & 30 & 30 & 120 \\
& $(100)$ & $(100)$ & $(100)$ & $(100)$ & $(100)$ \\
\hline
\end{tabular}

A question has been put to the respondents to know the opinion whether the university students are major beneficiary group of library resources and services. The replies given by them are shown in Table X. It is clear from the above Table that majority of the respondents $(48.33 \%)$ agreed that university students are major beneficiary group of library resources and services followed by $(47.50 \%)$ respondents strongly agreed and a few respondents $(4.17 \%)$ neutral.

TABLE XI IMPACT OF LIBRARY RESOURCES/SERVICES ON LEARNING

\begin{tabular}{|c|c|c|c|c|c|}
\hline \multirow{2}{*}{ 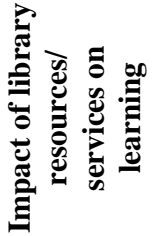 } & \multicolumn{2}{|c|}{ 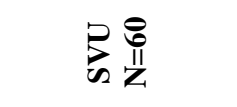 } & \multicolumn{2}{|c|}{ 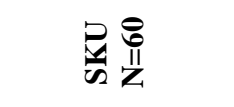 } & \multirow{2}{*}{ हี } \\
\hline & P.G & R.S & P.G & R.S & \\
\hline High & $\begin{array}{c}27 \\
(90.00) \\
\end{array}$ & $\begin{array}{c}28 \\
(93.33) \\
\end{array}$ & $\begin{array}{c}29 \\
(96.67) \\
\end{array}$ & $\begin{array}{c}26 \\
(86.67) \\
\end{array}$ & $\begin{array}{c}110 \\
(91.67) \\
\end{array}$ \\
\hline Moderate & $\begin{array}{c}2 \\
(6.67)\end{array}$ & $\begin{array}{c}2 \\
(6.67) \\
\end{array}$ & $\begin{array}{c}1 \\
(3.33)\end{array}$ & $\begin{array}{c}3 \\
(10.00)\end{array}$ & $\begin{array}{c}8 \\
(6.67)\end{array}$ \\
\hline Low & $\begin{array}{c}1 \\
(3.33)\end{array}$ & - & - & $\begin{array}{c}1 \\
(3.33)\end{array}$ & $\begin{array}{c}2 \\
(1.67)\end{array}$ \\
\hline Total & $\begin{array}{c}30 \\
(100) \\
\end{array}$ & $\begin{array}{c}30 \\
(100) \\
\end{array}$ & $\begin{array}{c}30 \\
(100) \\
\end{array}$ & $\begin{array}{c}30 \\
(100) \\
\end{array}$ & $\begin{array}{c}120 \\
(100) \\
\end{array}$ \\
\hline
\end{tabular}

A question has been put to the respondents to know the impact of library resources/services on their learning. The replies given by them are shown in XI. The response to the above question in Table XI shows that majority (91.67\%) of the respondents opined that there is high impact on their learning followed by $(6.67 \%)$ who felt that moderate impact is there and the remaining $(1.67 \%)$ who said that there is low impact on their learning habits.

TABLE XII PROBLEMS ENCOUNTERED WHEN USING LIBRARY SERVICES/RESOURCES

\begin{tabular}{|l|c|c|c|c|}
\hline \multirow{2}{*}{ Problems } & \multicolumn{2}{c|}{ SVU } \\
N=60 & \multicolumn{2}{c|}{$\begin{array}{c}\text { SKU } \\
\text { N=60 }\end{array}$} \\
\cline { 2 - 5 } & PG & RS & PG & RS \\
\hline $\begin{array}{l}\text { Textbooks are not } \\
\text { sufficient }\end{array}$ & $\begin{array}{c}29 \\
(43.33)\end{array}$ & $\begin{array}{c}28 \\
(46.67)\end{array}$ & $\begin{array}{c}30 \\
(50.00)\end{array}$ & $\begin{array}{c}30 \\
(50.00)\end{array}$ \\
\hline $\begin{array}{l}\text { Reference books are } \\
\text { insufficient }\end{array}$ & 30 & 30 & 30 & 30 \\
& $(50.00)$ & $(50.00)$ & $(50.00)$ & $(50.00)$ \\
\hline $\begin{array}{l}\text { Books are not shelved } \\
\text { properly }\end{array}$ & $\begin{array}{c}25 \\
(41.67)\end{array}$ & $\begin{array}{c}28 \\
(46.67)\end{array}$ & $\begin{array}{c}30 \\
(50.00)\end{array}$ & $\begin{array}{c}27 \\
(45.00)\end{array}$ \\
\hline $\begin{array}{l}\text { Textbooks are not } \\
\text { updated }\end{array}$ & $\begin{array}{c}30 \\
(50.00)\end{array}$ & $\begin{array}{c}30 \\
(50.00)\end{array}$ & $\begin{array}{c}30 \\
(50.00)\end{array}$ & $\begin{array}{c}29 \\
(48.33)\end{array}$ \\
\hline $\begin{array}{l}\text { Computers are not } \\
\text { sufficient }\end{array}$ & $\begin{array}{c}30 \\
(50.00)\end{array}$ & $\begin{array}{c}30 \\
(50.00)\end{array}$ & $\begin{array}{c}30 \\
(50.00)\end{array}$ & $\begin{array}{c}30 \\
(50.00)\end{array}$ \\
\hline $\begin{array}{l}\text { Internet speed is not } \\
\text { good }\end{array}$ & $\begin{array}{c}25 \\
(41.67)\end{array}$ & $\begin{array}{c}27 \\
(45.00)\end{array}$ & $\begin{array}{c}28 \\
(46.67)\end{array}$ & $\begin{array}{c}29 \\
(48.33)\end{array}$ \\
\hline $\begin{array}{l}\text { WI-FI facility not } \\
\text { available }\end{array}$ & - & - & 30 & 30 \\
\hline $\begin{array}{l}\text { Print journals are not } \\
\text { enough and updated }\end{array}$ & $\begin{array}{c}25 \\
(41.67)\end{array}$ & $\begin{array}{c}30 \\
(50.00)\end{array}$ & $\begin{array}{c}25 \\
(41.67)\end{array}$ & $\begin{array}{c}30 \\
(50.00)\end{array}$ \\
\hline $\begin{array}{l}\text { Competitive books are } \\
\text { not sufficient }\end{array}$ & $\begin{array}{c}30 \\
(50.00)\end{array}$ & $\begin{array}{c}27 \\
(45.00)\end{array}$ & $\begin{array}{c}24 \\
(40.00)\end{array}$ & $\begin{array}{c}26 \\
(43.33)\end{array}$ \\
\hline
\end{tabular}

The respondents were asked whether they face any problems while using library resources/services and their responses are highlighted in the above table. It is evident from the table XII that all the respondents identified nine major problems while using library resources and services; among them, Half of the SVU PG users reported that textbooks are not updated, reference books are insufficient, computers are not sufficient, competitive books are not sufficient are the main problems. The same 50 percentage of the Research Scholars also reported reference books are insufficient, textbooks are not updated, computers are not sufficient, print journals are not enough and updated are the main problems while using library resources and services.

When we getting to know SKU users problems, half of the PG users reported that textbooks are not sufficient, reference books are insufficient, books are not shelved properly, textbooks are not updated, and computers are not sufficient, WI-FI facility not available are the main problems. The same half of the percent of the Research Scholars also reported textbooks are not sufficient, reference books are insufficient, computers are not sufficient, WI-FI facility not available, print journals are not enough and updated are the main problems.

Table XIII displays university wise level of satisfaction of users with library resources and services. It shows that over three fourths of the SVU library users (88.33\%) are satisfied with furniture \& seating facilities. Over one fourth of the users are neutral or dissatisfied with electronic resources. 
Majority of the SKU library users $(83.33 \%)$ are satisfied with library staff behavior. 43.33 per cent users are neutral and 23.33 percent are dissatisfied with electronic resources.
It can be concluded that most of the SVU \& SKU library users are dissatisfied with electronic resources provided by central libraries.

TABLE XIII HOW SATISFIED ARE YOU WITH THE FOLLOWING RESOURCES AND SERVICES PROVIDED BY YOUR LIBRARY

\begin{tabular}{|l|c|c|c|c|c|c|}
\hline \multirow{2}{*}{ Satisfied Level } & \multicolumn{3}{|c|}{ SVU } & \multicolumn{3}{c|}{ SKU } \\
& $\mathrm{S}$ & $\mathrm{N}$ & $\mathrm{DS}$ & $\mathrm{S}$ & $\mathrm{N}$ & $\mathrm{DS}$ \\
\cline { 2 - 7 } & 47 & 8 & 5 & 31 & 20 & 9 \\
Print resources & $(78.83)$ & $(13.33)$ & $(8.33)$ & $(51.67)$ & $(33.33)$ & $(15.00)$ \\
\hline \multirow{2}{*}{ Electronic resources } & 30 & 13 & 17 & 20 & 26 & 14 \\
& $(50.00)$ & $(21.67)$ & $(28.33)$ & $(33.33)$ & $(43.33)$ & $(23.33)$ \\
\hline \multirow{2}{*}{ Library Services } & 49 & 4 & 7 & 42 & 10 & 8 \\
& $(81.67)$ & $(6.67)$ & $(11.67)$ & $(70.00)$ & $(16.67)$ & $(13.33)$ \\
\hline \multirow{2}{*}{ Furniture \& seating facilities } & 53 & 5 & 2 & 44 & 14 & 2 \\
& $(88.33)$ & $(8.33)$ & $(3.33)$ & $(73.33)$ & $(23.33)$ & $(3.33)$ \\
\hline \multirow{2}{*}{ Library staff behavior } & 46 & 8 & 6 & 50 & 6 & 4 \\
& $(76.67)$ & $(13.33)$ & $(10.00)$ & $(83.33)$ & $(10.00)$ & $(6.67)$ \\
\hline
\end{tabular}

The table XIII displays university wise level of satisfaction of users with library resources and services. It shows that over three fourths of the SVU library users $(88.33 \%)$ are satisfied with furniture \& seating facilities. Over one fourth of the users are neutral or dissatisfied with electronic resources. Majority of the SKU library users (83.33\%) are satisfied with library staff behavior. 43.33 per cent users are neutral and 23.33 percent are dissatisfied with electronic resources.

\section{CONCLUSION}

As found, the two university libraries have developed large collection of books, bound journals, current journals and databases (mostly e-journals and e-databases) and theses/dissertations over the years. However, regarding information sources and services, the major criticism as found that SVU \& SKU library users are dissatisfied with electronic resources followed by textbooks are not updated, reference books are insufficient, computers are not sufficient, competitive books are not sufficient. Based on various findings of the study, the following suggestions and recommendations are made: University libraries should pay serious attention to the systematic development of their electronic resources and their updating and maintenance on timely basis. With the emerging scenario or trend in view, university libraries should also focus on converting their physical resources into e-format so that the existing information resources are easily accessible for their effective use. With e-revolution at global level, it is the need of the hour to organize information resources for their easy access, create awareness about new information sources and services, developing user-centred library information systems, positioning of adequate library manpower, providing adequate financial support to libraries, focusing on development of automation, digitization and networking programmes, initiating programmes for education and training of library professionals and users for effective use of e-resources.

\section{REFERENCES}

[1] Dumebi, Otulugbu. (2017). Awareness and Use of Online Information Sources among University of Ibadan Students. International Journal of Library Science, 6(2), 37-41.

[2] Fatima, Farheen \& Tadasad, P. G. (2013). Users' Attitude towards Library Resources in a University Environment: A Case Study of Gulbarga University Library Gulbarga, International Research: Journal of Library \& Information Science, 3(2) 363-376.

[3] Javed Khan (2016). Awareness and use of resources and services in IIT Delhi Library: A Case Study. International Research: Journal of Library \& Information Science, 6(2).

[4] Kumar, V. D. \& Kumar, S. (2018). Use of information sources and services in employment information and guidance bureau library, Kuvempu University: A study. International Journal of Information Dissemination and Technology, 8(1), 50-53.

[5] Kurian, Binoy \& Nagarajan, M. (2018). Awareness and use of Open Access Resources among the Research Scholars of Annamalai University, Tamil Nadu : A Study, Journal of Advances in Library and Information Science ,7(1), 109-114.

[6] Mahajan, P. (2009). Information seeking behavior: a study of Punjub University, India. Library. Philosophy and Practice (e-journals) (March), 1-6.

[7] Ramadevi, Porika. (2016). Information Resources and Services in Public Libraries: A Case Study of Warangal District, Telangana State, India. E-Library Science Research Journal, 4(10), 1-7.

[8] Thanuskodi, S. (2012). Use of E-resources by the Students and Researchers of Faculty of Arts, Annamalai University. International Journal of Library Science, 1(1), 1-7.

[9] Zabed Ahmed, S.M. (2013). A survey of students' use of and satisfaction with university subscribed online resources in two specialized universities in a developing country, Library Hi Tech News, 30(3), 6-8. 